\title{
DEVELOPMENT PLANNING OF PALM OIL PLANTATION BASED ON SUSTAINABLE DEVELOPMENT IN EAST KOTAWARINGIN DISTRICT
}

\author{
Waldianto Wendy*, Zauhar Soesilo, Sarwono \\ Faculty of Administrative Science, University of Brawijaya, Indonesia \\ *E-mail: wendy.waldyanto@gmail.com
}

\begin{abstract}
Agriculture is the most dominant sector of Gross Regional Domestic Product (PDRB) of East Kotawaringin District. The sub-sectors with the most contribution in the agricultural sector are the plantation sub-sector, and the most dominant plantation commodities are palm oil plantations. Sustainable Development can be realized if a development has realized sustainability in three aspects, namely: Economic, Social, and Environment. While in fact palm oil plantations only sustainable on the economic aspects alone, while the environmental aspects and social aspects are often set aside. Therefore, a planning strategy is needed to enable the development of palm oil plantations based on Sustainable Development in East Kotawaringin District. The purpose of this thesis research is to explain and analyze: 1) Planning program of East Kotawaringin District Government to overcome the negative impact of palm oil plantation development, 2) Sustainable development effort by third parties on planning of palm oil plantation development in East Kotawaringin District, 3) sustainable development strategy that is suitable to be applied in palm oil plantation development planning in East Kotawaringin District. This research uses qualitative method with descriptive approach. The results showed that the development of palm oil plantations in East Kotawaringin District only sustainable on economic aspects and social aspects only, while for the environment is still not sustainable. To handle this the strategy that should be done is to use three stages of input-process-output. Input is an identification of several planning documents, and a number of public complaints about palm oil plantation issues. Process is an activity of analysis and discussion about the result of identification at input stage. Output is the result of discussion between the government, the company, and the community set forth in a program of palm oil plantation development activities that are Sustainable Development.
\end{abstract}

\section{KEY WORDS}

Planning, sustainable development, palm oil, plantation.

East Kotawaringin District is a district with potential of potential land resources, where the palm oil plantation sector is the largest utilization of space for Large Private Plantations / Large State Companies and Smallholders Estate. The contribution of the agricultural sector in the formation of East Kotawaringin District's PDRB in the last 5 years (2010-2015) averaged $37,07 \%$ per year. Of this number, the contribution of plantation's sub-sector occupies the highest position in agricultural sector, with an average of $14,6 \%$ per year, while other sectors in the agricultural sector are: Food Crops Sub-sector 6,90\%, Sub Sector Fisheries 5,10\%, Forestry Sub-sector 6,80\%, Livestock Sub-Sector 3,70\%.

Rencana Tata Ruang Wilayah Provinsi (RTRWP) stipulated in Central Kalimantan Regional Regulation No. 08 of 2003 which divided the forest area of $10.294 .853,52 \mathrm{Ha}$ $(67,4 \%)$ and non-forest area of $5.061 .846,48 \mathrm{Ha}(32,96 \%)$. However, the fact is that in Central Kalimantan Province there is a very critical land area of $2.383 .923 \mathrm{Ha}$, critical area of 2.100.046 Ha, slightly critical of $2.786 .880 \mathrm{ha}$, thus the total critical land is $7.270 .850 \mathrm{Ha}$.

The immediate impacts felt by East Kotawaringin District in relation to the arrangement, planning and investment process in palm oil plantations that are less concerned about environmental and social factors are the changing of physical condition of geographical, social and environmental order. To go to the sustainable management of palm oil plantations, it is necessary to consider several aspects of policy such as: economic, social, 
and environment. The management of sustainable palm oil plantations in East Kotawaringin District can be used as a first step to solve the overall problem of conflict resolution at the field level.

\section{LITERATURE REVIEW}

Regional Development Planning. According to the city planner, Conyers and Hill (Hariyono, 2010) mention that planning is an ongoing process that produces decisions, or options about possible alternative resource use, with the aim of achieving a part of the objective of a certain period of time in the future.

Planning typology is divided into four kinds based on theoretical thinking. The four kinds of planning can be explained as follows (Fianstein and Norman, 1991):

1. Traditional planning. In this type of planning the planner sets out the intent and purpose of changing a defective city system.

2. User-Oriented Planning. The concept of planning is to create a plan that aims to accommodate the users of the planning product, in this case the urban community.

3. Advocacy Planning. In this plan contains a program of defense of marginalized communities in the process of urban development, in this case the urban poor.

4. Incremental Planning. On planning that is supportive of a decision-making process on urban issues.

Sustainable Development Concepts. The Sustainable Development concept provides a new discourse on the importance of preserving the natural environment in the future. Sustainable development consists of three main pillars of economic, social, and environment that are interdependent and reinforcing. These three aspects cannot be separated from each other, because they cause-effect relationships. Economic and social relations are expected to create a fair relationship (equitable). The relationship between economy and environment is expected to continue (viable). While the relationship between social and environmental aims to continue to survive (bearable). The three aspects of economic, social and environmental aspects will create sustainable conditions (sustainable) (Wijaya, 1991).

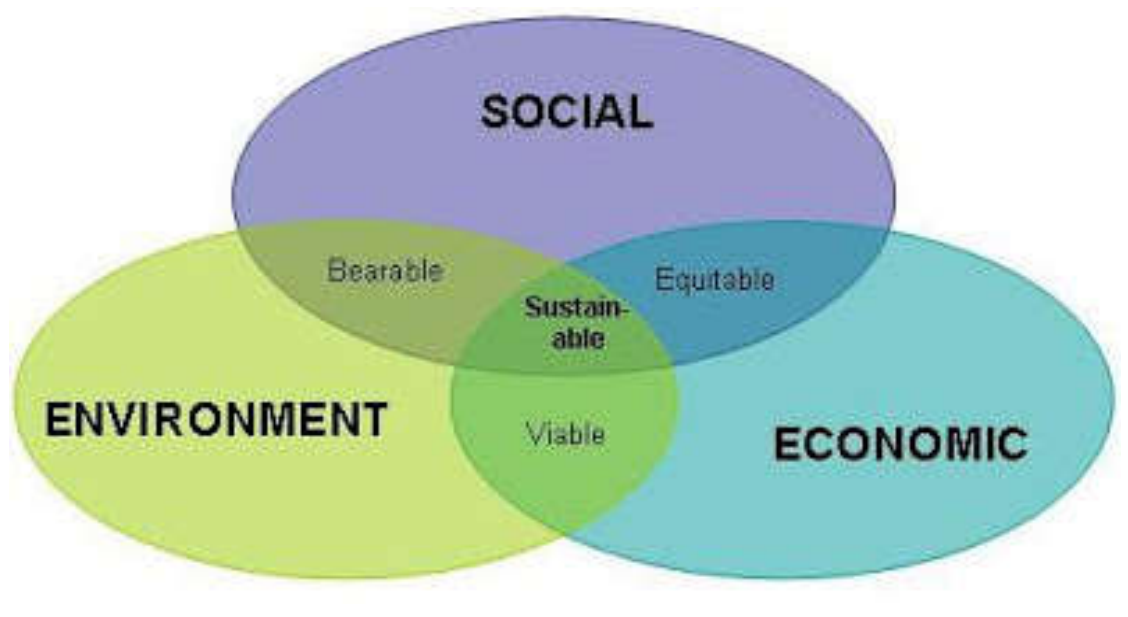

Source: Wijaya. 1991.

Figure 1 - Sustainable Development Aspects

Economic sustainability is defined as a development that is able to produce goods and services continuously to maintain the sustainable government. Environmental sustainability is defined as an environmentally sustainable system must be able to maintain a stable resource, avoiding the exploitation of natural resources and environmental absorption functions. Social sustainability, social sustainability is defined as a system capable of achieving equality, the provision of social services including health, education, gender, and political accountability. 


\section{METHODS OF RESEARCH}

This research uses qualitative research method with descriptive approach type. The focus of this research is: (1) Planning program for palm oil plantation development from East Kotawaringin District Goverments; (2) Efforts to apply Sustainable Development to palm oil plantation development planning by three parties: government, corporations, and communities; (3) Sustainable Development Strategy in palm oil plantation development planning in East Kotawaringin District.

Research location in East Kotawaringin District, located at Environment Agency, Forestry and Plantation Agency, and Regional Planning and Development Agency. Sources of data from this research are informants, events, and documents. Data collection technique is done through interview, observation, documentation study. Next, data analysis techniques used are spiral data analysis techniques developed by lan Dey (2005), as follows:

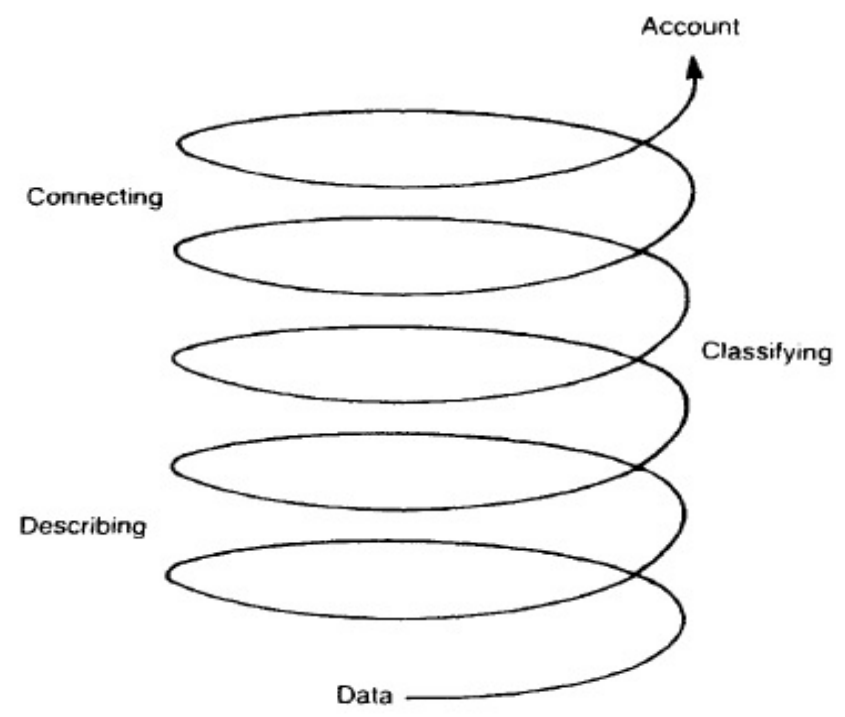

Source: Dey. 2005.

Figure 2 - Data Analysis Techniques: Spiral Model

\section{RESULTS AND DISCUSSION}

Planning Programs from the Government in Overcome the Negative Impacts of Palm Oil Plantation Development. Negative environmental impacts such as the function of forest land conversion will be catastrophic environmental damage. Conversion of natural forests is still ongoing until now even more crazy because of lust Central Kalimantan Provincial Government who want to make palm oil as a major source of foreign exchange for the economy in the Province of Central Kalimantan.

Negative impacts from the social side are the occurrence of overlapping conflicts between companies and communities. But the intensity of the conflict from year to year has tended to decrease. The thing that causes the intensity of the conflict to decline is because the company always provides the appropriate empowerment program to the community around the plantation. So that the good or bad public perception in this case is determined by the attitude of the company itself.

To overcome these environmental and social problems, the clearing of land for palm oil plantations should be limited and should be diverted to other commodity functions whose production is not inferior to palm oil commodities, and certainly this commodity is more environmentally friendly. The commodities referred to here are rubber plant which is also a superior commodity of East Kotawaringin District.

In addition the East Kotawaringin District Government has also formulated several programs to overcome the negative impact of palm oil plantation development as set out in 
the document of Spatial Plan of East Kotawaringin District, as follows: redistribution of forest area and non forest area; setting the balance of sustainable utilization of space by considering the carrying capacity and capacity of the environment and the sustainability of natural resources; development of agriculture in a broad sense; development of processing industry; space utilization for the sake of achieving economic growth and improving the welfare of the community.

Each Parties Efforts in Realizing Sustainable Development on Development Planning of Palm Oil Plantations. Efforts of East Kotawaringin District Government in realizing sustainable development are as follows: First, East Kotawaringin District has a duty to facilitate a forum of deliberations that discuss the efforts of sustainable development in the development of palm oil plantations. Second, the preparation of co-chairs is done by the Government of East Kotawaringin District by preparing the team to conduct environmental conservation to every palm oil plantation company operating in East Kotawaringin District. Third, East Kotawaringin District Government must apply strict sanctions for plantation companies that do not implement environmental conservation programs, and which do not support the efforts of sustainable development.

Efforts of palm oil plantation companies to realize sustainable development are as follows: First, the maintenance and environment conservation such as maintenance and conservation can be seen through the efforts of land empowerment, crop and environmental treatment, harvesting and production process, up to the provision of plasma plantations for the community around the plantation. Second, the community empowerment program by palm oil plantation companies, one example is the partnership program (plasma). This program is intended to help communities around plantations that own land but do not have the capital to manage the land. Third, is the provision of conservation area. For the provision of this conservation area, the researcher considers that there are still many palm oil plantation companies in East Kotawaringin District that have not yet provided conservation area on their palm oil plantations. This is because there is no special regulation from the government that regulates the sanctions given to companies that are not cooperative.

Efforts of the community in realizing sustainable development are as follows: First, to contribute labor to palm oil plantation companies, so that companies can run the wheels of the economy. Second, provide support for every activities undertaken by palm oil plantation companies. Third, submit a complaint about the problem of palm oil plantations based on three aspects, namely: economic, environmental, and social to East Kotawaringin District Government through the nearest urban village office or sub-district office.

Sustainable Development Strategy in Development Planning Process of Palm Oil Plantation in East Kotawaringin District. Development planning process of palm oil plantation development that leads to the realization of sustainable development can be done through three stages namely: Input, process, and output. This planning process will synchronize between the regulation with the factual conditions that occur in the field. Then the synchronization result between the two matters will be discussed transparently and jointly by East Kotawaringin District Government, palm oil Plantation Company, and community representative.

These input stages are the stages that will see some inputs consisting of some planning documents, and some of the issues about palm oil plantations that have been complained by the community to the government. The planning document from East Kotawaringin District Government that will be seen is RPJMD, RTRW. While the planning documents of the company is RPL, as well as some problems of palm oil plantations that are complained by the community to the government.

Stages of the process are divided into two activities namely the analysis activities, and discussion activities. The first activity is an analysis which is an activity to analyze some planning documents and also root problem analysis to some of the complaints from the community. Then, the second activity carried out at the stage of the process is a discussion which is a synchronization between the results of the analysis of some planning documents and the results of the analysis of the root causes of problems complained by the community. 


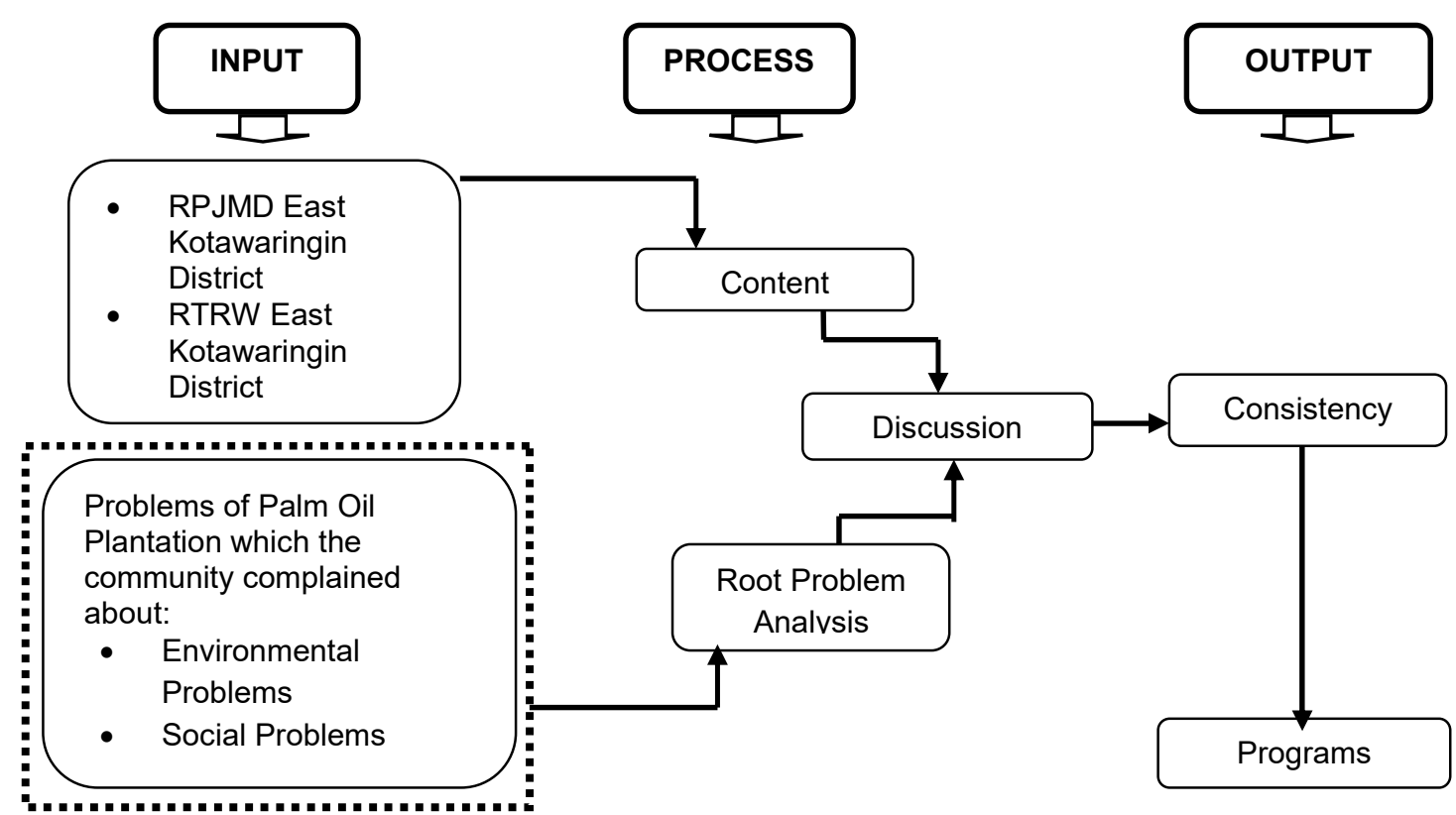

Source: Charts Processed Researcher, 2016.

Figure 3 - Development Planning Strategy of Palm Oil Plantation Based on Sustainable Development

This stage of output is the final stage of all activities undertaken during this planning process. Having been declared consistent with some existing programs in other planning documents relating to palm oil plantations then set a program related to palm oil plantation development. Of course the program to be set must also accommodate some problems that have been complained by the community to the Government of East Kotawaringin District, so the problems are indirectly will come solved by the implementation of the program.

\section{CONCLUSION}

Palm oil plantations development in East Kotawaringin District is currently only sustainable on social and economic aspects, while for the environment is not sustainable. The three parties namely: the government, the company, and the community have been able to coordinate together to undertake palm oil plantations development in East Kotawaringin District. But in terms of environmental conservation, the government and the company has not been so optimal in performing its duties. For the company, many still do not obey the government's instruction for the provision of conservation area. As for the government there is still no stipulation of local regulations that regulate specifically the provision of sanctions to palm oil plantation companies that do not make efforts to conserve the environment. Development planning strategy of palm oil plantations to be sustainable must be done through three stages of input-process-output. Input is the basis of the planning, the input consists of some planning documents and complaints by the community. The process is an analysis process and discussion conducted by the three parties namely: the Government of East Kotawaringin District, palm oil plantation companies and the community. Output is analysis result in the form of determination of development programs to realize palm oil plantation based on Sustainable Development.

\section{REFERENCES}

1. Dey, I. (2005). Qualitative Data Analysis. Routledge, New York.

2. Fianstein (1991). City Planning and Political Value. Journal of Urban Affairs Quarterly, 2(3).

3. Hariyono, P. (2010). Perencanaan Pembangunan Kota dan Perubahan Paradigma. Pustaka Belajar, Yogyakarta.

4. Wijaya, S. (1991). Pembangunan Berkelanjutan: Konsep dan Kasus. Tiara Wacana, Yogyakarta. 